\title{
Recyclable material collectors and COVID-19 in Brazil: actions and reflections
}

Recolectores de material reciclable y covid-19

en Brasil: acciones y reflexiones

\author{
Rafael Silva ${ }^{1 * \odot}$
}

1 Universidade Federal do Rio Grande do Sul. Porto Alegre, Brasil.

\section{SOUTH} SUSTAINABILITY

Cite as: Silva, R. (2021). «Recyclable material collectors and COVID-19 in Brazil: actions and reflections». South Sustainability, 2(1), e033.

DOI: https://doi.org/10.21142/SS-02012021-c001

Artículo recibido: 5/1/2021 Arbitrado por pares

Artículo aceptado: 25/1/2021

\section{(c) (1)}

(c) El autor, 2021. Publicado por la Universidad Científica del Sur (Lima, Perú)

${ }^{*}$ E-mail de correspondencia: rafael.mozart@ufrgs.br

\section{Dear Editor,}

Globally, Brazil ranks second in the number of people infected by COVID-19, with current figures standing at 21,381,790 cases and 595,446 deaths (WHO, 2021). COVID-19, besides being a significant threat to global health, can also be considered a negative factor in the economic, political and social advancement of affected countries (Huang et al., 2020; Ranjbari et al., 2021). In this context, recycling has been strongly impacted by the pandemic, particularly those activities engaged in by recyclable material collectors, as the rate of waste production is directly related to the degree of development of a country's productive forces, both in terms of the quantity and variety of materials discarded and their spatial concentration, particularly in national capitals and metropolitan areas (Fidelis and Colmenero, 2018; Tsai, 2021). I have examined with particular interest the work of Flores (2020), published in the previous edition of this journal. The article addresses the critical problem of plastics in the context of the pandemic. Given the journal's interest in this topic, I would like to offer my own comments regarding recyclable material collectors in Brazil, as a complement to the excellent contribution of offered by the author.

In Brazil, recyclable material collectors, in general, are people who engage in this activity in order to ensure their survival or because recycling is feasible in the context of the immediate needs imposed upon them for survival in a dynamic labor market. According to estimates from the National Movement of Waste Pickers (MNCR) of Brazil, currently around 800,000 waste pickers are working in the country, and they are responsible for collecting $90 \%$ of the total recyclable material in Brazil (IPEA, 2013). Waste pickers earn their living by collecting recyclable materials and waste and selling reusable materials to the recycling market.

The COVID-19 pandemic has directly impacted the lives of recyclable material collectors in Brazil in terms of their health and financial prospects. According to de Sousa (2020), these workers are frequently exposed to contamination and infection by the virus. Consequently, they are rendered unable to engage in their activities and can no longer obtain the income required for their subsistence.

During the pandemic, there has been an increase in demand for food delivery services, and increased use of disposable hospital supplies such as masks and gloves. According to the Plastic Atlas 2020, there has been an increase in plastic consumption in Brazil during the coronavirus pandemic (STIFTUNG, 2020). Therefore, plastic recycling might have been expected to have boomed 
for recyclable material collectors in Brazil; however, the waste collection and treatment structure is precarious, despite the fact that the country has a National Solid Waste Policy, as defined by Law No. 12305, dated August 2 2010, which although it has been implemented is far from ideal.

Policies and legal changes aimed at recyclable material collectors, who are generally low income workers, are an essential step towards the formalizing of recycling organizations. Also, while the pandemic has led to the need for greater resilience among citizens across the globe in order to withstand the effects of the current crisis being experienced by nations' healthcare systems, recyclable material collectors require particular consideration, because they are actively exposed to COVID-19.

We are facing a pandemic of overwhelming proportions, with coronavirus having brought societies to a virtual standstill, both in developed and developing nations (Sarkis et al., 2020). Internationally, through a collective and combined effort, scientific knowledge and resources have been marshaled in order to develop vaccines to mitigate the spread and the effects of COVID-19. This experience may also serve to encourage citizens throughout the world to adopt more sustainable production and consumption practices.

\section{Bibliographical references}

De Sousa, F. D. B. (2020). «Pros and cons of plastic during the COVID-19 pandemic». Recycling, 5(4), pp. 1-17. doi: 10.3390/recycling5040027

Fidelis, R. and Colmenero, J. C. (2018). «Evaluating the performance of recycling cooperatives in their operational activities in the recycling chain». Resources, Conservation and Recycling, 130(July 2017), pp. 152-163. doi: 10.1016/j.resconrec.2017.12.00.

Flores, P. (2020). «La problemática del consumo de plásticos durante la pandemia de la covid-19». South Sustainability, 1(2), pp. e016-e016. doi: 10.21142/SS-0102-2020-016

IPEA, I. de P. E. A. (2013). «Situação social das catadoras e dos catadores de material reciclável e reutilizável». Texto para discussão - IPE, p. 76. Available at: http://www.ipea.gov.br/portal/images/stories/PDFs/ situacao_social/131219_relatorio_situacaosocial_mat_reciclavel_ brasil.pdf

Sarkis, J. et al. (2020). «A brave new world: Lessons from the COVID-19 pandemic for transitioning to sustainable supply and production». Resources, Conservation and Recycling, 159(January). doi: 10.1016/j. resconrec.2020.104894

Stiftung, H. B. (2020). Atlas do plástico - Fatos e números sobre o mundo dos polímeros sintéticos. Available at: https://br.boell.org/ pt-br/2020/11/29/atlas-do-plastico

Tsai, W. T. (2021). «Analysis of plastic waste reduction and recycling in Taiwan». Waste Management and Research, 39(5), pp. 713-719. doi: $10.1177 / 0734242 \times 21996821$

WHO (2021). WHO Coronavirus (COVID-19). Dashboard, World Health Organization. Available at: https://covid19.who.int/ (Accessed: 9 August 2021) 